\title{
The use of manipulative didactic material to teach concepts related to the treatment of information for visually impaired students
}

\author{
a Universidade Tecnológica Federal do Paraná (UTFPR), Grupo de Pesquisa O Ensino e a Inclusão de Pessoas \\ com Deficiência, Guarapuava, PR, Brasil

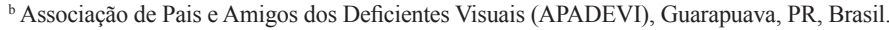 \\ ${ }^{\mathrm{c}}$ Universidade Tecnológica Federal do Paraná (UTFPR), Programa de Pós-Graduação em Ensino de Ciência \\ e Tecnologia (PPGECT), Ponta Grossa, PR, Brasil \\ d Faculdade Guairacá, Programa de Pós-Graduação em Promoção da Saúde (PPGPS), Guarapuava, PR, Brasil \\ e Programa de Pós-Graduação em Ensino de Ciências e Educação Matemática - PPGECEM. \\ ${ }^{\mathrm{f}}$ Universidade Tecnológica Federal do Paraná (UTFPR), Programa de Pós-Graduação em Ensino de Ciência e Tecnologia \\ (PPGECT), Ponta Grossa, PR, Brasil
}

Received for publication on 1 Dec. 2019. Accepted after review on 6 Apr. 2020.

Designed editor: Claudia Lisete Oliveira Groenwald

\begin{abstract}
Context: teaching mathematics to visually impaired students has been challenging teachers in classrooms. Thus, it is important to use manipulative resources for the teaching process. Objective: to evaluate the use of manipulative didactic material for teaching concepts related to the treatment of information for students with visual impairments. Design: applied nature and qualitative approach. Environment and participants: held at a special education school in a countryside municipality in the state of Paraná. The participants were two visually impaired students and a mathematics teacher specialized in the area. Data collection and analysis: semi-structured interview, pre-test and post-test composed of five questions elaborated based on the contents proposed by the National Curriculum Parameters - PCN, and recordings of the classes taught by the responsible teacher. The data collected were examined through the analysis of the conversation, theoretically based on Piotr Yakovlevich Galperin's assumptions on the formation of mental action through steps. Results: revealed that the material developed for this study is a mediating tool in the process of forming mathematical concepts by the participating students, showing the importance of using differentiated resources that allow visual impaired students to access and appropriate knowledge taught at school. Conclusions: based on the appropriation of visually impaired students on how to deal with the material used in the study, we suggest to apply the material to EJA classes; inclusive classes; students with intellectual disabilities and/or disorders such as dyscalculia.
\end{abstract}

Keywords: Mathematics teaching; Visual impairment; Manipulative didactic material; Treatment of information.

Corresponding author: Eliziane de Fátima Alvaristo.Email: elizianeclaro@hotmail.com 


\section{O uso de material didático manipulável no ensino de conceitos relacionados ao tratamento da informação para estudantes com deficiência visual}

\section{RESUMO}

Contexto: o ensino de matemática para estudantes com deficiência visual vêm sendo um desafio aos professores em salas de aula. Desse modo, é importante a utilização de recursos manipuláveis para o processo de ensino. Objetivo: avaliar o uso de um material didático manipulável para o ensino de conceitos relacionados ao tratamento da informação para estudantes com deficiência visual. Design: natureza aplicada e abordagem qualitativa. Ambiente e participantes: realizado em uma escola de educação especial de um município no interior do estado do Paraná. As participantes foram duas estudantes com deficiência visual e uma professora de matemática especializada na área. Coleta e análise de dados: entrevista semiestruturada, pré-teste e pós-teste compostos de cinco questões elaboradas com base nos conteúdos propostos pelos Parâmetros Curriculares Nacionais - PCN, e gravações das aulas ministradas pela professora responsável. Os dados coletados foram examinados por meio da análise da conversação, fundamentando-se teoricamente nos pressupostos teóricos de Piotr Yakovlevich Galperin sobre a formação da ação mental por meio de etapas. Resultados: revelaram que o material elaborado para esse estudo, constituiu-se como uma ferramenta mediadora no processo de formação de conceitos matemáticos pelas estudantes participantes, evidenciando a importância da utilização de recursos diferenciados que permitam aos estudantes com deficiência visual o acesso e a apropriação dos conhecimentos ensinados na escola. Conclusões: com base na apropriação das estudantes com deficiência visual no uso do material utilizado no estudo, sugere-se a aplicação do material para turmas da EJA; turmas inclusivas; estudantes com deficiência intelectual e com transtornos como a discalculia.

Palavras-chave: ensino de matemática; deficiência visual; material didático manipulável; tratamento da informação.

\section{INTRODUCTION}

Studies show the importance of using manipulative teaching material for teaching mathematics to students with or without visual impairments (Shimazaki, Silva \& Viginheski, 2015; Vita, Magina \& Cazorla, 2015; Pereira \& Oliveira, 2016; Silva, Carvalho \& person, 2016; Mello, Caetano \& Miranda, 2017). Despite the considerable increase in the past two decades of manipulative teaching materials for teaching mathematical content to visually impaired students, there are still shortcomings, especially for teaching content related to the treatment of information.

In the case of the blind student, the manipulative didactic material allows the reception of information about the object of study through tactile perception. Besides the access to information, its utilization provides new forms of learning, with the appropriation of the concepts taught and action on the object of knowledge. The material becomes a tool in the effectiveness of the teaching and learning process (Fernandes \& Healy, 2010; Silva, Carvalho \& Pessoa, 2016; Pereira; Oliveira, 2016). It is noteworthy, however, that the use of the material alone does not guarantee learning, it must be associated with a planned and intentional pedagogical practice. For this, it is necessary a teaching that plans and enables students to act on objects, allowing them to make use of language and thought to solve problem situations that are posed to them daily (Galperin, 2009a; 2009b). 
The theory of the formation of actions through steps, proposed by Galperin (2009b), considers that, in the learning process, the student needs to interact with the object of knowledge, with the teacher and with his peers. From this, the theorist established some teaching steps, including the formation of action in the material or materialized plane, in the external language plane and in the internal language or mental plane.

In the material or materialized plane, the teacher provides the student with direct contact with reality, acting on material objects or their representation. The activities proposed in this step are carried out in pairs or in groups, under the mediation of the teacher. The students relate to the objects themselves and carry out external manipulative actions. After this step, there are the steps of formation of actions in the external language and mental plane.

The action formation step in the external language plane is related to the interaction and/or communication between teacher and students. According to Núñez (2009, p. 111), "[...] language is an instrument - a tool of learning activity that allows sharing and giving meaning to learning objects". Through language, the limits of the sensory perception of the outside world are exceeded. In this step, the elements of the action represent, in oral or written form, their transformation until reaching the logic of the concepts on the mental plane.

Finally, the mental step is the initiation of verbal execution for oneself. Communication is replaced by reflection, when the student moves from external language coding to the mental internalization of content, providing a new way of thinking (Galperin, 2009c).

The teaching of content related to the treatment of information in the National Curriculum Parameters of Mathematics - PCN (Brazil, 1997) allows students to organize and analyze different information in school routine, family relationships, social networks or other occasions, through the collection of data on the subject researched, through the representation of those data in tables and graphs and, finally, through the analysis and interpretation of the data and its influence on their daily lives.

In the case of graphics, based on the teaching process, sighted students can elaborate them using common tools such as ruler, square, compass, protractor and others. For visually impared students to build graphics, tools to enable the substitution of visual elements by other forms of actions are needed, such as those contained in tactile elements. In the intricacies of teaching content related to the treatment of information, the present study aims to evaluate the use of manipulable didactic material for teaching concepts related to the treatment of information for students with visual impairment.

\section{METHODOLOGY}

This is an applied research work with a qualitative approach. The study was carried out in an elementary school, in the special education modality, located in the countryside of the state of Paraná.

The study sample consisted of two blind students enrolled in the 9th grade of elementary regular schools. They attended the counter shift in a special education school that offered assistance in the area of visual impairment, through complementary 
support services to regular education that included Braille, Soroban, Orientation and Mobility, Support to Schooling, Activities of Daily Living, among others. To guarantee the anonymity of the students, the language was impersonalized, and they were given a student code E, and assigned numbers 1 and 2. The teacher responsible for the schooling support service offered to students also participated in the research.

Before the research was carried out, the project was submitted to the Ethics Committee, being approved through Review no. 2.703.478, issued by the Ethics and Research Committee of the Federal University of Technology of Paraná - UTFPR, on June 9, 2018.

In the study, the manipulative didactic material Adapted Pie Chart ${ }^{1}$ was used for the construction of graphs in sectors by visually impared students. The material is based on Galperin's theory for the formation of action through steps and on the PCN guidelines (Brazil, 1997) for the 9th grade of elementary school.

The material, made of MDF, consists of a square plate with a hollow circle. Its circumference is divided into 72 equal parts, by means of a small embossed line, with a measurement equal to $5^{\circ}$. The inner part of the circle is also divided into 72 parts, by means of equidistant embossed radiuses. The pieces have different textures to represent the fractions of the circle. The material is represented by Figure 1:

Figure 1 Manipulative didactic material Adapted Pie Chart.

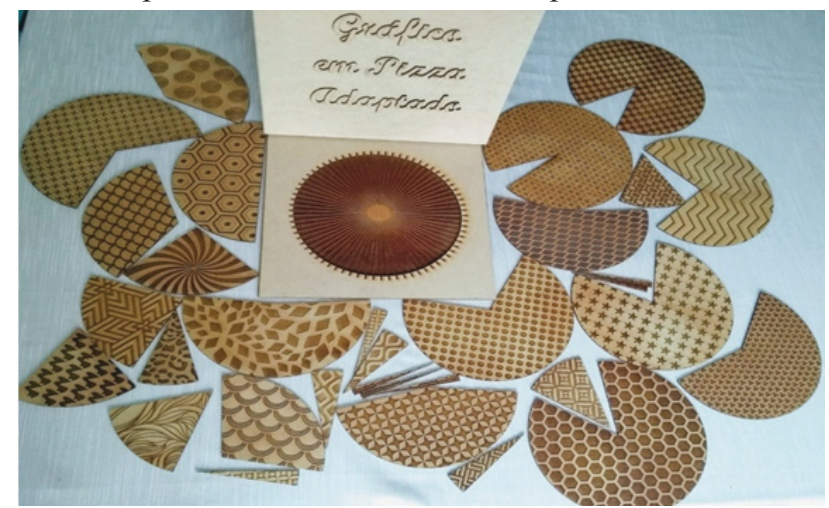

Figure 1. Manipulative didactic material Adapted Pie Chart. (Alvaristo, 2019)

An assessment was applied to the students at two moments of the research, before the development of the pedagogical intervention by the specialist teacher and after the conclusion of the activities. Firstly, the assessment was called a pre-test and aimed to verify the knowledge that the students had about concepts related to the elaboration of graphs in sectors. Secondly, the same evaluation was applied as a post-test, aiming at verifying the students' conceptual changes. The evaluation consisted of five multiple-choice questions,

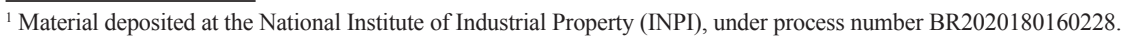


written in Braille and with graphs adapted for haptic reading from the questions presented in Chart 1. It is noteworthy that, when preparing this assessment, we considered that the students had already had access to the knowledge provided for in the mathematics PCNs (Brasil, 1997) for the final years of elementary school in regular education.

I. A survey was carried out in a class of 35 students about their preference in the use of social media. $43 \%$ of the students chose WhatsApp, 29\% Instagram, 14\% Facebook and 14\% Snapchat. Considering this information, answer the following questions:

How many students prefer Facebook:
a) 4.9
b) 5
c) 2
d) 10

II. Which graph best presents the results of the survey:

a)

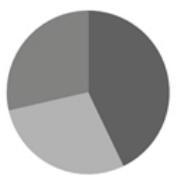

b)

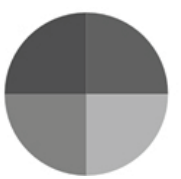

c)

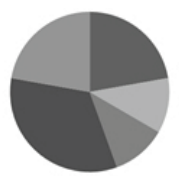

d)

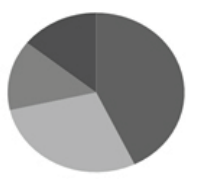

III. How many degrees measures the sector that represents the preference for WhatsApp approximately:

a) $50^{\circ}$

b) $105^{\circ}$

c) $155^{\circ}$

d) $200^{\circ}$

A company conducted a survey on the preference for tools to share content on the Web, the results of which are shown in the following graph:

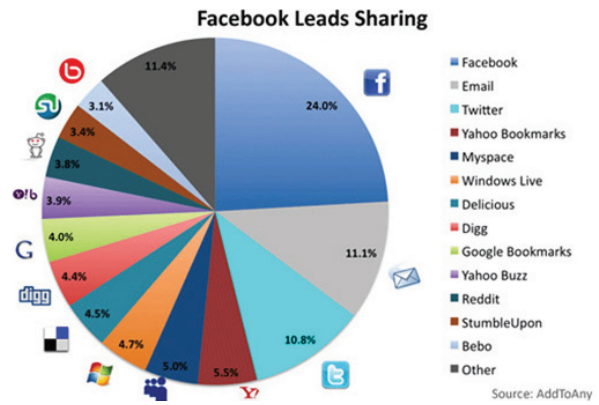

IV. Which media does the people surveyed use the most?

a) E-mail

b) Twitter

c) Facebook

d) Windows Live

V. Considering that 2.000 people participated in the survey, how many people prefer to publish their content on Twiter?

a) 215

b) 217

c) 150

d) 216

Chart 1. Pre- and post-test questions. (Alvaristo, 2019) 
In the interval between the pre-test and the post-test, the schooling support teacher developed activities with the students about the representation of data in graphs in sectors.

The students were invited to conduct a survey with their colleagues in the regular education on their preference for social media. The questions were printed in Braille and transcribed in ink. The respondents made an embossed mark on their answers, allowing students to know what the answers were and to compute the results with autonomy and independence. Chart 2 presents the research content:

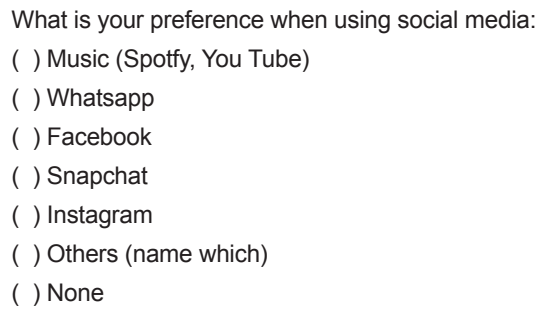

Chart 2. Research on preference for social media. (Alvaristo, 2019)

After collecting the data, the students, guided by the specialist teacher, tabulated them, defined the percentage of the sample in relation to the total of students in the schools, calculated the percentage of each of the social media, according to the students' preference, converted the percentages in degrees and built a pie chart corresponding to the data collected.

For the development of these activities, the Braille typewriter, the Soroban and the Dos Vox calculator were used. The Adapted Pie Chart didactic material was used to teach how to represent data in graphs in sectors, as well as to analyze and interpret the information displayed in such graphs. Those activities were carried out for a period of three classes, lasting $2 \mathrm{~h}$ each.

The teacher's classes were recorded and, after the full transcription of the footage, episodes were selected for analysis, categorized into: knowledge already consolidated by the students, type of guidance, the role of manipulative material in the formation of concepts and language as a way to internalize the concepts covered.

During the development of the activities, there was a dialogue between the researcher and the teacher through an informal interview. It addressed issues related to the progress of activities, clarification of doubts, readjustments of activities and different ways of approaching them, recorded in a field diary. After the application of the posttest, a semi-structured interview was conducted with the teacher, which was recorded, to collect other information that was not expressed in the pre and post-test, nor identified in the class recordings. 
The results obtained in the pre and post-test were analyzed quantitatively and the results of the pedagogical intervention and the interviews with the teacher were examined through the analysis of the conversation, focusing on the context of the subjects' actions and their interpretations. After the transcription of the films, the data analysis took place through the following steps: i) reading of the transcriptions; ii) data organization and ordering; iii) identification of episodes through categorization and iv) confirmation of findings through the theoretical framework adopted (Flick, 2009).

\section{RESULTS AND DISCUSSION}

\section{Initial assessment}

In the pre-test, E1 got one and E2 got two correct answers out of the five questions proposed. According to the schooling support teacher, the results of the pre-test revealed that the students may not yet have appropriated concepts necessary for learning the content related to the treatment of information covered in the research. We think that evaluating the students' knowledge only through this instrument could lead to a very narrow interpretation of their learning, since the results did not express the way the students solved the problems to find the answers. In fact, the teacher investigated the concepts they had about percentage and rule of three. The following excerpts present a dialogue between the teacher and the students (E1; E2).

Teacher: Do you know how to calculate percentages?

E1: The teacher taught once, I've forgotten it now.

Teacher: Why do you think you've forgotten?

E1: I don't remember, it was a long time ago. I think it was in the sixth grade that I learned it. I don't remember it now.

Teacher: And rule of three, did you learn?

E1: Not yet.

Q: Can you calculate a percentage?

E2: I think I can.

Q: How do you do it?

E2: Divide and multiply by 100 ?

Q: It is something like that, but do you use the rule of three?

E2: Yes, I have already learned it.

Q: How many percent does the whole class (34 students) represent?

E2: 100 .

Q: And six students?

E2: Six students? I think about $10 \%$.

Q: And how did you find the $10 \%$ ?

E2: (Does not answer) 
These two excerpts show that both students had regular education access to knowledge related to the percentage and the rule of three. It was also evident that they were aware of some steps required for resolution, such as that the percentage calculation was related to 100 , and that $100 \%$ represented the whole. However, it can be considered that neither consolidate this knowledge. E1 forgot how to do it and although E2 indicated some ways to do it, she was unable to use knowledge to find the result of the percentage of the class group, of how many percent a group of six students represented in the whole.

The teacher observed that the students found some calculations difficult. E1 used mental calculus, for example, multiplications by 10 , by 100 ; E2, did not. The student was unable to calculate $11 \times 5$ mentally, for example, she had to calculate it with Soroban. E1 did the same operation mentally.

Both students did not know how to multipliply and divide by two figures, such as 400:17; they were also unable to perform these operations with decimal numbers.

Both students E1 and E2 found it difficult to solve first degree equations, such as grouping variables and constants. Both commented to the teacher that, at school, they used material adapted in Braille (textbook/math booklet). The development of mathematical activities in writing was not common. They solved the problems orally most of the times, which was evidenced mainly by E2.

\section{The guiding basis for action and external language in the intervention carried out by the specialist teacher}

In most teaching moments, the teacher sought a form of teaching that would allow students to act on the object of knowledge. Whenever possible, the teacher prompted the students to carry out the activities independently, giving guidance whenever necessary. For Galperin (2009d), the guidelines of students' action through mediation allows students to learn and generalize appropriate concepts in different situations.

When verifying that the students did not have certain knowledge, the teacher explained how they should proceed, also justifying many actions related to basic mathematics teaching that are left out in ordinary teaching. As an example, the explanation given by the teacher when solving the algebraic equation 17.x =100.4. At first, E1 solves the multiplication 100.4, resulting in the equation $17 \cdot x=400$ :

Q: In this equation, we need to find the value of $\mathrm{x}$. What do we need to do for this?

E1: I don't know the value of $\mathrm{x}$.

Q: Then, we will use the reverse operation. 17 is multiplying $x$. We need to eliminate it. For that, do you remember that mathematics works like the scales, that everything you do on one side, you do on the other?

E1: Yes.

Q: If you multiply by 17 , what will happen if you divide by 17 ? 


\section{E1: I will get the value of $x$.}

Q: You are going to eliminate 17 and be left with $\mathrm{x}$. If you divide the first member of the equation by 17, you will divide the second by 17 as well. Then it will be $\mathrm{x}=400: 17$.

Additionally, the teacher taught her how to make rule of three for E1, given that she needed this concept to be able to carry out the activities proposed.

The teacher could simply have explained the rule of three algorithm, given examples and asked for the resolution of the percentages that the study required, in the same way as in traditional teaching. However, the teacher made use of the dialogue to extract from the students the knowledge they had about those calculations. To explain the rule of three, the teacher said: "The rule of three is used when you know three values and want to find a fourth value. The total of students in the class, the percentage that this number represents and the number of students who like music. But don't you know the percentage of these students who listen to music?".

According to the teacher, it was necessary to return to concepts of reason and proportion so that there was an understanding of the concepts related to the simple rule of three and the percentage. For this, the teacher made use of the data obtained in the interview, and, together with the students, organized the proportion of the group she had chosen in a given social network, comparing it with the total of the class through the rule of three. She also taught the students all the steps to organize the data; calculate the absolute and relative frequencies by calculating the percentage for each social network; transform of the percentage found in an angle measure (degree); and elaborate a graph in sectors.

The mediation as the guiding basis for action allows the action to be carried out in an autonomous, creative and productive way, with the students' participation in the learning process (Núñez, 2009).

It is noteworthy that, at times, the teacher, when questioning the students, did not give them time to answer her questions. An example, when the teacher asked E2 how many percent represented the three students in her survey about music. The student answered any number, not solving the question correctly. The teacher immediately said that it was better to do it by the rule of three, without giving the student an explanation of how the student arrived at the result presented. The same situation was observed in another dialogue with student E2:

Q: How much is $3 \times 100$ ?

E2: I think it's 500 .

Q: Do it with Soroban.

E2: (Takes the Soroban, records the numbers and performs the multiplication operation) It is 300 .

P: Right. It will be $3 \times 100=300$ 
In this case, the teacher could have asked the student what the equation would look like after solving the multiplication. In both cases, the teacher was immediatist, not allowing the students to reflect on their actions and make decisions.

\section{The use of manipulative material in the concept formation process}

After the collection, the organization of the survey data and the calculations of the relative frequencies in percentage, the students explored the manipulative didactic material Adapted Pie Chart. The presentation of the material took place step by step, so that the students could understand from the touch, the ergonomics of the material, all the pieces separetely. It started with the presentation of the hollow circle on the square plate, divided into 72 equal parts. The teacher asked the students to calculate the measure in degrees of each part. Both needed the teacher's help to perform the calculation using the Soroban. Then, after making the percentage calculations and transforming them into angle measurements, the students were presented with the pieces that contained the material so that they could explore by touching the different textures of each piece, understanding how these pieces complemented each other inside the circle.

Figure 2 shows the students using the Adapted Pie Chart didactic material:

Figure 2 Students elaborating a graph in sectors.

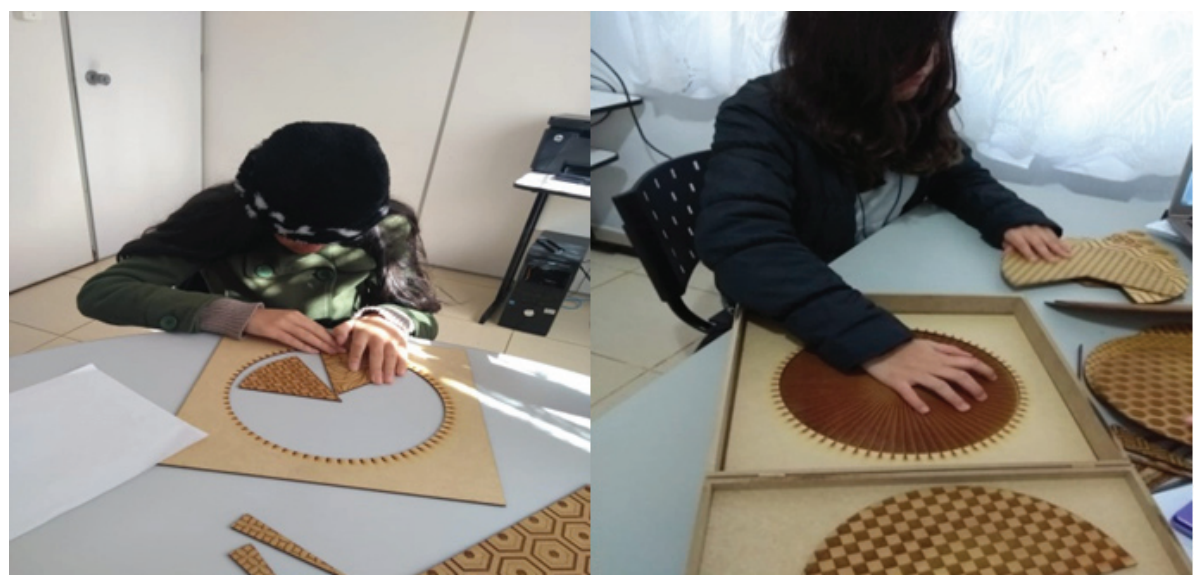

Figure 2. Students elaborating a graph in sectors. (Alvaristo, 2019)

We found that the activities developed, from the research with their peers, to the elaboration of the graph, motivated the students to study the contents proposed. Talizina (1987) shows that there must be reasons that encourage students to all circumstances linked to their routine of life and the place that the student occupies in the collective.

The use of manipulative didactic material Adapted Pie Chart, based on the guidance given by the specialist teacher, allowed students to represent graphically the data collected, 
promoting the contextualization of the content taught in situations they had experienced. Núñez (2009) argues that it is important to teach students to identify, recognize and use the necessary and sufficient characteristics of the object of study to understand the concept. In this perspective, the material fulfilled the function of being a tool for learning, in the step of action formation in the material or materialized plane.

\section{Language as a way to internalize the concepts covered}

Language played a very important role in all stages of research in the teaching and learning process. For Galperin (2009c), the steps of action formation are not hermetic, they are divided, and they happen interconnected to each other. During the pedagogical intervention, the teacher talked and problematized with the students the content related to the treatment of information and the data collected by the students, so that they could reflect and act on the object of knowledge. For Vygotsky (2001), language fundamental in the process of appropriation of the mathematical concepts taught, since it enables people to seek auxiliary instruments for solving tasks, establishing a strategy of action, and controlling their own behavior.

The highlighted excerpt follows the importance of the dialogue between the student and the teacher in carrying out a division operation using Soroban:

Q: We will divide 360 by 72 with Soroban.

E2: I can't do it with two numbers.

Q: Can you divide 3 hundreds to 72 ?

E2: No, I can't.

Q: So, what do you have to do?

E2: Divide 36 tens?

Q: Can you divide by 72 ?

E2: Ouch, no.

Q: You can't, right? So, let's get 360 units. How many 72 s do you have in 360 ?

E2: I don't know.

Q: So let's think about how many $7 \mathrm{~s}$ you can have in 36 .

E2: $7 \mathrm{x} 4$.

Q: $7 \times 4$ is 28 , can't it be more?

E2: Five, then?

Q: Register 5 and let's see if it works. How much is $5 \times 2$ ?

E2: 10 .

Q: And what do you have to do?

E2: Take 10 out?

Q: Take 10 out of 360 (350 left in Soroban). 
Q: How much is $5 \times 7$ ?

E2: 35

$\mathrm{Q}:$ And thirty-five minus thirty-five?

E2: Zero.

Q: So, how many degrees does each space have on the circumference?

E2: Five degrees.

As can be seen in this dialogue, language made it possible an independent action of the use of materials (sharing objects), becoming reasoning about them.

During the activities, no moments were observed when the teacher asked the students for explanations about their actions, so that they externalized the way their actions proceeded. This would enable students to transform their actions towards the object of study into the very act of talking about the content learned. According to Galperin (2009c), verbal action is structured not only as a reflection of its action on the object, but also as a communication of itself, subordinated to the student's understanding and the meaning attributed to these actions.

\section{Final assessment}

For the analysis of the formation of the action on the mental plane or the internal language plane and the contribution of the manipulative teaching material Adapted Pie Chart, the combined results of the pre and post-test applied to the students are highlighted, referring to the 'information processing' content. (Table 1).

It is noteworthy that, according to the students' information, none of them had had contact with graphs in mathematics classes in regular education, and the fact that the specialist teacher worked with the students to create graphs in sectors, may have influenced the results of the final evaluation.

Table 1

Pre and Post-Test Results: (Alvaristo, 2019)

\begin{tabular}{|c|c|c|c|c|c|c|c|c|c|c|c|c|}
\hline & \multicolumn{2}{|c|}{ Q1 } & \multicolumn{2}{|c|}{ Q2 } & \multicolumn{2}{|c|}{ Q3 } & \multicolumn{2}{|c|}{ Q4 } & \multicolumn{2}{|c|}{ Q5 } & \multicolumn{2}{|c|}{ CORRECT } \\
\hline & PRE & POST & PRE & POST & PRE & POST & PRE & POST & PRE & POST & PRE & POST \\
\hline E1 & C & C & I & I & I & I & I & C & I & I & 1 & 2 \\
\hline E2 & C & $\mathrm{C}$ & I & C & I & C & I & C & C & C & 2 & 5 \\
\hline
\end{tabular}

Legend: C - Correct; I - Incorrect.

The formation of action in terms of internal language was considered, in this study, from the moment that the students started to carry out the activities alone, independently, revealing their abstract perception. This could be verified at the time of the post-test, 
when they could express the knowledge acquired in solving the activities proposed in the evaluation, without the teacher's help.

In the pre-test, E1 got only one question right. In the post-test, she got two questions right. According to the student, in the regular school, the teaching process occurred only through orality, without the use of any manipulative didactic resource, which made it difficult to understand the basic concepts about the applied content. According to the specialist teacher, E1 was on the way to appropriating those concepts, requiring only more time for pedagogical intervention.

E2 answered correctly two of the questions in the pre-test and five in the posttest. In the same way as in the pre-test, it cannot be said that there was a consolidation of the concepts based only on the results of the post-test. Some episodes found in the transcription of the footage and presented in previous sessions show that the students had not yet consolidated several concepts necessary for the treatment of information, however, they were on the way to consolidating them.

The role of the teacher also stands out. When she found that the students had not aprehended concepts about the rule of three and calculating percentages, she initially developed the first calculations with the students. E1 also needed help to perform the second calculation and, starting from the third, she performed it alone, with success. E2 needed support for a longer time, however, at a later time, when she needed to resume this knowledge, she indicated the necessary steps for the resolution. This also highlights the fact that students are on their way to appropriating knowledge.

From the results obtained, some reflections are presented. It seems to be common for teachers working in regular education to use orality as a single strategy for teaching mathematical concepts to blind students. Viginheski et al. (2014, p. 914) emphasize that the teacher:

[...] using only orality to teach mathematics to blind students, or using resources adapted only for the demonstration of content, can contribute to the emergence of gaps in their learning, since important details for the appropriation of these contents are not considered. In both situations, the blind student is a spectator, not participating actively in the process of building the concepts covered.

For Galperin (2009a), it is essential that the teacher uses other manipulative didactic resources in the teaching and learning process, enabling visually impared students to appropriate the contents covered and respecting their development process, without skipping teaching steps. Hence the importance of the teacher making use of other channels to receive information other than vision. This can also be considered for students who do not have any type of disability.

Regarding the use of the Adapted Pie Chart, it was considered in this study that its use included the step of action formation in the material or materialized plane. Viginheski 
et al. (2014) emphasize that learning is a complex and unfinished process. Therefore, the more encouragement the students have in the use of manipulative teaching materials, the greater their chances of success in learning mathematical content.

According to Lorenzato (2008), the teaching process for blind people using manipulative, physical objects is important, because it facilitates the appropriation of the concepts involved in these objects so that they can later perform the mental representation those concepts.

In teaching blind students, the material can be used in different situations, and, concurrently with its use, the teacher has the possibility of inserting another form of adaptation used for visually impaired students, the description (Valente, 2010). With this, the student will be able to elaborate the mental image of the graph and, later, be able to analyze and interpret other graphs represented only through description.

Language allows sharing and giving meaning to learning objects (Núñez, 2009). Through it, students reached other steps from the material or materialized step, reflecting on their actions in order to establish more complex relationships, when they no longer manipulated the material. Galperin (2009c) evidence that this process is the beginning for the formation of concepts. The verbal action is structured as a reflection of the action performed with the object, since for the theorist, the mental step begins with the appropriation of the content taught. The appropriation of the content occurred in succession to the other steps, the material and the verbal ones.

It was found in the steps of this research that the students had not yet appropriated concepts that had already been taught in regular education. One of the factors that may have contributed to this is the mechanical, repetitive teaching, in which students are not given the opportunity to act on the object of knowledge. Concepts are considered by Vygotsky (2001) a complex act of thought. When taught through training or repetition, memorization happens, rather than learning. In the case of E1, over time, what was once memorized was forgotten.

Often, in schools, teachers use orality mainly to teach visually impaired people. Thus, the concepts are only presented to them, not giving them the opportunity to participate in the process as a whole. Indeed, students complete basic training without appropriating knowledge (Viginheski et al., 2014).

It is noteworthy that the responsibility for teaching the scientific concepts, and in the case of the research, mathematical concepts, lies with the teacher of regular education. Currently, special education develops its work together with the regular education, previously it was considered a reference for the education of people with disabilities (Brasil, 2008). This can lead teachers of regular education to a misinterpretation, believing that the student will have access to knowledge in the multifunctional resource classrooms. The specialist teacher is not always trained in mathematics, the area of knowledge of this research, and if the student does not have access to the contents of this discipline in regular education, gaps and difficulties will arise in the learning process. 


\section{CONCLUDING REMARKS}

The results show that the Adapted Pie Chart teaching material helped students to build graphs in sectors autonomously, allowed the material to be easily handled, and made it possible for students to identify the pieces through tactile perception; it also brought contributions to the inclusive teaching of mathematics, by allowing the participation of visually impaired students in the teaching and learning process, promoting the appropriation of mathematical knowledge.

Some limitations were identified in this study. The first was the time used for the development of pedagogical interventions, and the fact that the material was used by only two blind students. This can interfere with the research findings, hence the importance for the material to be validated by other blind people.

Another limitation concerns the fact that analysis and interpretation activities of other research works represented by means of graphics in sectors were not included. Despite not having been included in this research, E1 answered correctly question IV in the post-test, and E2 answered questions II and IV correctly too. Both questions required reading and interpreting pies.

In the teaching process, the description of the charts elaborated could be inserted concomitantly with the use of the Adapted Pie Chart, fostering the students' access to this type of adaptation. We also suggest that the material for teaching concepts related to the treatment of information should be applied for a longer period of time for students with visual impairments; for EJA and inclusive classes; for students with intellectual disabilities; and for students with disorders such as dyscalculia.

\section{AUTHORS' CONTRIBUTION DECLARATIONS}

A. F. E. developed the Adapted Pie Chart manipulative didactic material, application, methodology, theory for the research and collected the data. S. R. C. S. developed the Adapted Pie Chart manipulative didactic material, supervised the project and guided the research theory. V. M. V. L. developed the Adapted Pie Chart manipulative didactic material, application, methodology and theory for research. P.A.L. developed the Adapted Pie Chart manipulative didactic material, supervised the project, guided the adaptation of the methodology and the theory of the research. All authors discussed the results and contributed to the final version of the manuscript.

\section{DATA AVAILABILITY STATEMENT}

The data supporting the results of this study will be made available by the corresponding author, A.F.E., upon reasonable request. 


\section{ACKNOWLEDGMENTS}

This work was carried out with the support of the National Council for Scientific and Technological Development (CNPq), Brazil.

\section{REFERENCES}

Alvaristo, E. F. (2019). Uma ferramenta para elaboração de conceitos matemáticos para estudantes com deficiência visual: gráfico em pizza adaptado (103f.). Dissertação Mestrado em Ensino de Ciência e Tecnologia. Universidade Tecnológica Federal do Paraná. Ponta Grossa. Disponível em: http://repositorio.utfpr.edu.br/jspui/handle/1/3992

Brasil. (1997). Secretaria de Educação Especial. Parâmetros Curriculares Nacionais: Matemática. Brasília: MEC/SEF/SEESP. Disponível em: http://portal.mec.gov.br/seb/ arquivos/pdf/livro03.pdf.

Brasil. (2008). Secretaria de Educação Especial. Politica Nacional da Educação Especial na Perspectiva da Educação Inclusiva. Brasília: MEC/SEF. Disponível em: http:// portal.mec.gov.br/index.php?option=com_docman\&view $=$ download\&alias $=16690$ politica-nacional-de-educacao-especial-na-perspectiva-da-educacao-inclusiva05122014\&Itemid $=30192$

Fernandes, S. H. A. A. \& Healy, L. (2010). A inclusão de alunos cegos nas aulas de Matemática: explorando área, perímetro e volume através do tato. Bolema: Boletim de Educação Matemática, Rio Claro, 23(37), 1111-1135. Disponível em http://www.redalyc. org/html/2912/291221915012/

Flick, U. (2009). Introdução à pesquisa qualitativa.3 ed. Porto Alegre: Artmed.

Galperin, P. Y. (2009a). La formacion de las imágenes sensoriales y los conceptos. In: Rojas, L. Q. \& Solovieva, Y. Las funciones psicológicas en el desarrollo del niño. México: Trillas.

Galperin, P. Y. (2009b). La formacion de los conceptos y las acciones mentales. In: Rojas, L. Q. \& Solovieva, Y. Las funciones psicológicas en el desarrollo del niño. México: Trillas.

Galperin, P. Y. (2009c). La direción del processo de aprendizaje: In: Rojas, L. Q. \& Solovieva, Y. Las funciones psicológicas en el desarrollo del niño. México: Trillas.

Galperin, P. Y. (2009d). Tipos de orientación y tipos de formación de lasacciones y los conceptos. In: Rojas, L. Q. \& Solovieva, Y. Las funciones psicológica en el desarrollo del niño. México: Trillas.

Lorenzato, S. (2008). Para aprender Matemática. 2. ed. Campinas: Autores Associados.

Núñez, I. B. (2009). Vygotsky, Leontiev e Galperin: formação de conceitos e princípios didáticos. Brasília.

Pereira, J. S. \& Oliveira, A. M. P. (2016). Materiais manipuláveis e engajamento de estudantes nas aulas de Matemática envolvendo tópicos de geometria. Ciência \& Educação, Bauru, 22(1), 99-115. Disponível em: https://dialnet.unirioja.es/servlet/ articulo?codigo $=5379166$ 
Shimazaki, E. M; Silva, S. C. R. \& Viginheski, L. V. M. (2015). O ensino da Matemática e a diversidade: o caso de uma estudante com deficiência visual. Interfaces da educação, 6(18), 148-164. Disponível em: https://periodicosonline.uems.br/index.php/interfaces/ article/view/1082/913

Silva, M. D; Carvalho, L. M. T. L. \& Pessoa, C. A. S. (2016). Material manipulável de geometria para estudantes cegos: Reflexões de professores brailistas. Revista Paranaense de Educação Matemática, Campo Mourão, 5(9), 176-202. Disponível em: http://www. fecilcam.br/revista/index.php/rpem/article/viewFile/1264/pdf_196

Talizina, N. F. (1987). La formación de la actividad cognoscitiva de los escolares. La Habana: ENPES.

Valente, D. (2010) Os diferentes dispositivos de fabricação de imagens e ilustrações táteis e as possibilidades de produção de sentido no conhecimento perceptivo dos cegos. Revista Educação, Arte e Inclusão, 2, 59-82. Disponível em: http://www.revistas.udesc. br/index.php/arteinclusao/article/view/1991

Viginheski, L. V. M. et al. (2014). O sistema Braille e o ensino da Matemática para pessoas cegas. Ciência \& Educação, Bauru, 20(4), 903-916. Disponível em: https:// dialnet.unirioja.es/servlet/articulo?codigo $=5041202$

Vita, A. C; Magina, S. M. P. \& Cazorla, I. M. (2015). A probabilidade, a maquete tátil, o estudante cego: uma teia inclusiva construída a partir da análise instrumental. Jornal Internacional de Estudos em Educação Matemática, 8(3), 55-97. Disponível em: http:// revista.pgsskroton.com.br/index.php/jieem/article/view/3046/2843

Vygotsky, L. S. (2001). Pensamiento y linguaje. Obras Escogidas 2. Madri. 